\title{
Prospects and Challenges of the Animation Industry in Bangladesh
}

\author{
Md. Bharul Islam ${ }^{1}$, Abu Kalam Shamsuddin ${ }^{1}$ and Moshiur Rahman Choudhury ${ }^{2}$ \\ ${ }^{1}$ Department of Multimedia Technology and Creative Arts, Daffodil International \\ University, Dhaka-1207, Bangladesh \\ baharuledaffodilvarsity.edu.bd, shamsuddin@daffodilvarsity.edu.bd \\ ${ }^{2}$ Chief Executive Officer, Dreamer Donkey Private Limited, Dhaka, Bangladesh \\ moshiurrahman@dreamerdonkey.com
}

\begin{abstract}
Many developing countries are successfully developing their animation industries which are already contributed to their economic growth. It is noted that these countries have the potentials to become hubs for working international quality animation products due to low labor cost. For the purpose of reviewing the prospects of these industries, in Bangladesh, the researchers visited some selected animation studios in the capital city. Data was collected from 16 animation and multimedia studios using direct interviews, telephone conversations, and website visits etc. The main purpose of this study is to find out the prospects and challenges of animation industries in Bangladesh.
\end{abstract}

\section{KEYWORDS}

Animation, Advertisement, Bangladesh, Film industries, Marketing

\section{INTRODUCTION}

To animate means to give life a still objects [1]. It can create images that seem real to viewers. Many 3D movies are very believable and are commonly used as visual effects for recent movies [2]. The production of animation is an important part of the creative economy. There are many sectors of the creative like in including TV, film, advertising, new media, and computer and video games [3]. It also provides entertainment including animated feature films, television series, and live entertainment for audiences around the world. A transformation is involved for animating an object that will be moving. The human eye retains an image for 0.1 seconds. So when more than 10 frames per second of an animated film run through a projector, the flow of motion on the screen looks seamless. Normally animation shot on film and projector is played at 24 frames per second [4]. Technology is becoming more powerful and user-friendly. Animators seem to be highly satisfied in their jobs. Animator is one of the most creatively fulfilling jobs. Animation involves teamwork, creativity and innovative problem solving as a career. Cinema is the greatest media which can easily portray a country, its population, ideas, philosophy and cultures. In this modern era one does not need to watch cinema in cinema hall as it can also be very much available at home. But still a huge population goes to cinema halls. Cinema is like a window of a society. A country and its customs, society, people are mostly reflected through a cinema. So we can also say it is a mouthpiece of a society. This is the strongest media which can portray the pros and cons of a society [5]. The long cherished demand of film artists has been fulfilled through government's recognition of film and 
film related activities as an industry. Bangladesh has also issued a guideline on allowing government grants for making short films, 2011[6].

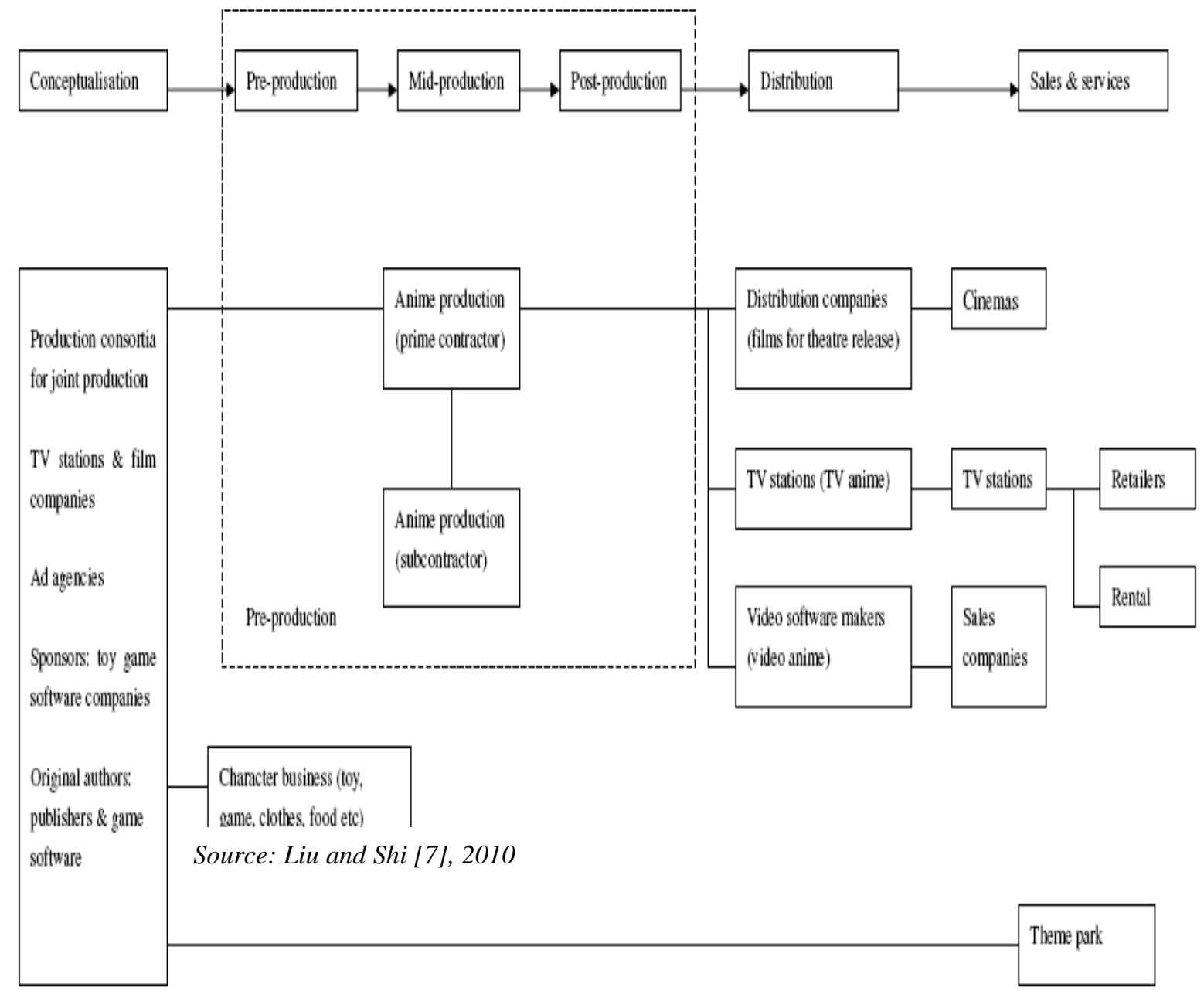

Figure 1: Block diagram of production process of an animation industry

\subsection{Global Trends in Animation Market}

Bangladeshi's population is 161 million (July 2012 e at. www.indexmundi.com/bangladesh). There are lots of possibilities to create skill people; animation is one of potential area in Bangladesh. Evidently, from 1998 to date, 100 Bangladeshi people started working with animation; with a remarkable growth rate of $85 \%$. As animators in outsourced countries such as Bangladesh, India develop their skills, they could potentially take over more of the work traditionally done in the USA or Europe. With US as one of the most significant market in the world as shown in figure 2. All these trends bring pressure on animators to continue to evolve as artists and stay current with new technology. The skill level in the industry is improving and the competition is intensifying [9]. 

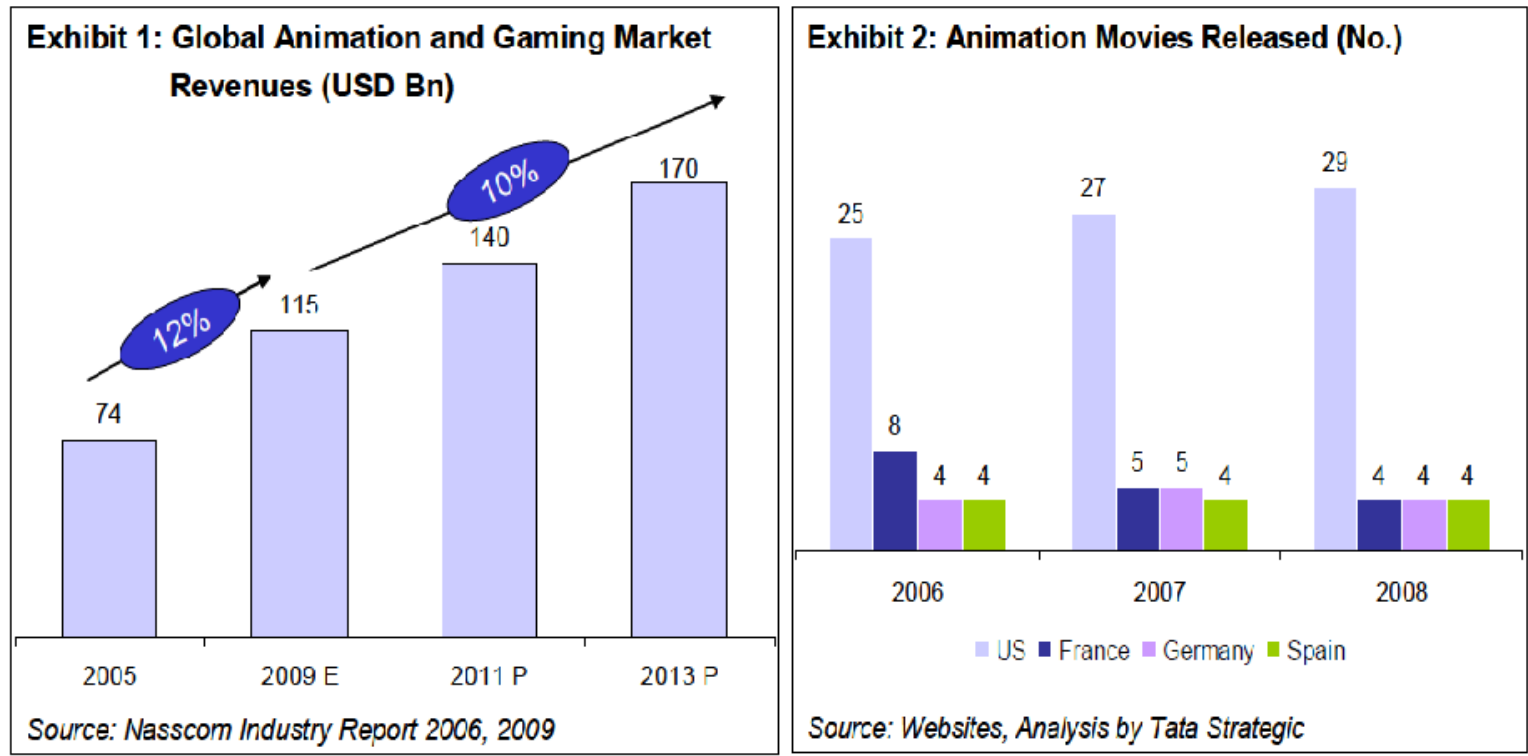

Figure 2: Global animation and gaming market revenues (Exhibit 1) and Animation movies released in numbers (Exhibit 2) [8]

\subsection{Market Overview in Bangladesh}

Bangladesh has the highest population density of any country, except city-states such as Singapore. This country has experienced fairly robust economic growth during the last decade, which saw the restoration of a democratically elected government and a steady, albeit slow, liberalization of the economy [10]. Real GDP growth for the year 2005 is provisionally reported as $5.38 \%$. Inflation rates have continued to rise, averaging 7.97\% FY2013 (Source: Bangladesh Bureau of Statistics, 2013).

\subsection{Copyright Law in Bangladesh}

International Intellectual Property Alliance (IIPA) requests the government of Bangladesh take the following actions [11]:

- Establish an anti-piracy force

- Establish a cell to intercept imports and exports.

- Inspect all optical disc plants, collecting exemplars and closing down plants engaged in piracy, seizing pirate discs and materials, and prosecuting owners and managers of pirate plants.

- Pass and implement an effective optical disc regulation including licensing requirements

There are a number of reasons for growing animation firm as well as multimedia institutions. First, the industry has a high economic importance in the global economy. Second, the availability of rich data makes the industry particularly appealing from a research perspective [12]. Economically, developing countries recognize the opportunities brought about by the globalization of the film business and strive to benefit from it [13]. China had put into effect many policies in promoting its native animation industry [14]. Tschang and Goldstein [15] present a framework for explaining production patterns in creative industries. The animation industry in China has grown rapidly [16]. 
Michael [17] worked on force character design from life drawing. Drawn animation method as well as 2D animation techniques described briefly in all steps [18]. Thomas and Johnston [19] worked on character animation in life and principles of animation. Access Economics has estimated the economic contribution of the film and television industry to the Australian economy [20].

\section{RESEARCH METHODOLOGY}

We collect information from 16 animation as well as multimedia industries from Bangladesh using different Methods: physical interviews, telephone communications and website visits. The information was like name of the industries, year of establishment, number of employees, activities, revenue per calendar year, challenges, procedure for overcome problem, future prospects locally and globally. The duration of information collection was April 2013 to June 2013. Table 1 describes the data collection methodology from different animation industries in Bangladesh.

Table 1Data collection methods

\begin{tabular}{|l|c|c|c|}
\hline Name of the Institute/ Studio/ Industry/University & Direct & Telephone & Data from \\
\hline AAVA 3D & $\mathrm{X}$ & & \\
\hline Animedia Arts & & & $\mathrm{X}$ \\
\hline Daffodil International Professional Training Institute & $\mathrm{X}$ & & \\
\hline Dot 3 Production (Pvt) Limited & $\mathrm{X}$ & & \\
\hline Dreamer Donkey & $\mathrm{X}$ & & \\
\hline Latitude-23 & & $\mathrm{X}$ & \\
\hline Kento Studios LTD & & & $\mathrm{X}$ \\
\hline Nayantara Communications & & & $\mathrm{X}$ \\
\hline National Institute of Mass Communication & & & $\mathrm{X}$ \\
\hline Ogniroth Studio & $\mathrm{X}$ & & \\
\hline Roopokar Creative Studio & & $\mathrm{X}$ & \\
\hline RTC Hubs Privet Ltd & & $\mathrm{X}$ & \\
\hline Sketch Studio Limited & & & $\mathrm{X}$ \\
\hline Studios Click house & & $\mathrm{X}$ & \\
\hline SW Multimedia Ltd & & $\mathrm{X}$ & $\mathrm{X}$ \\
\hline Toon Bangla & & \\
\hline
\end{tabular}

Working environment is one of the factors to produce high quality outcome. Figure 3 shows the working environment of one of Dot 3 Production Private Limited. 
International Journal of Computer Graphics \& Animation (IJCGA) Vol.3, No.3, July 2013

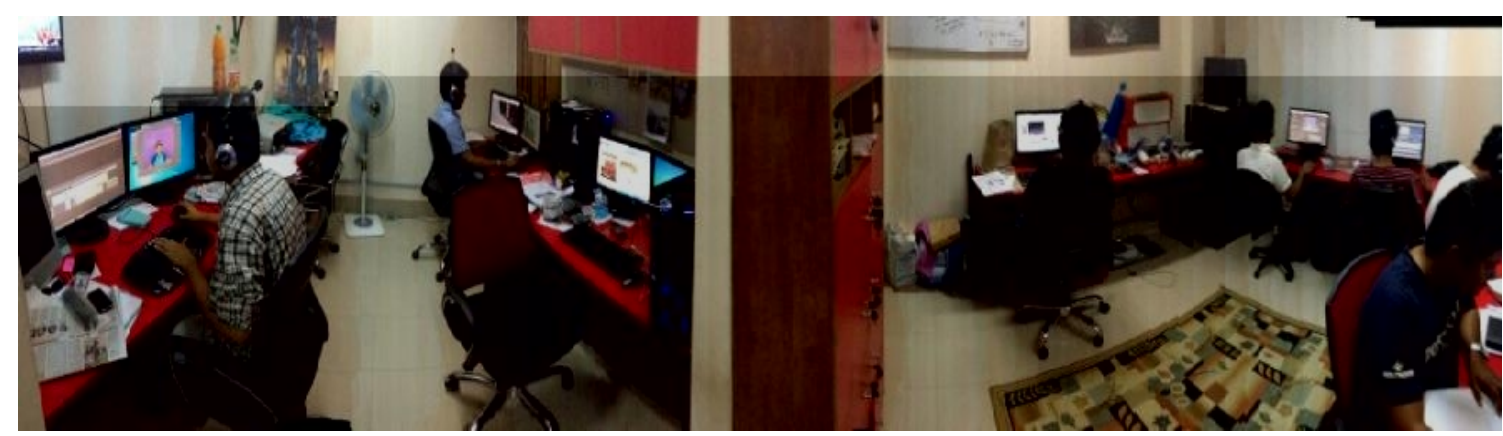

Figure 3: working place in Dot 3 Production Private Limited (Image taken June 3, 2013)

\section{OUTCOME RESULTS}

Table 2 Summary of selected animation industries

\begin{tabular}{|c|c|c|c|}
\hline Name of Company & $\begin{array}{l}\text { Starting } \\
\text { Year }\end{array}$ & Working Area & Contact \\
\hline Dreamer Donkey & 1997 & Animation & Telephone: +8801727174563 \\
\hline Ogniroth & 2010 & Animation & Mohammadpur, Dhaka 1207 \\
\hline $\begin{array}{c}\text { Daffodil International } \\
\text { Professional Training Institute }\end{array}$ & 1998 & Training & Panthapath, Dhaka-1205 \\
\hline Dot3 Production(Pvt)Ltd. & 2013 & $\begin{array}{c}\text { Video Production, 3D } \\
\text { Modeling }\end{array}$ & Rampura, Dhaka 1219 \\
\hline Aava3D & 2010 & $\begin{array}{l}\text { Animation, Motion } \\
\text { Graphics }\end{array}$ & Mirpur, Dhaka 1216 \\
\hline Latitude-23 & 2003 & $\begin{array}{c}\text { Graphics, Animation, } \\
\text { Gaming } \\
\end{array}$ & Mahakhali New DOHS.Dhaka \\
\hline Animedia Arts & N/A & Animation & Elephant Road,Dhaka-1205 \\
\hline Nayantara Communications & 2004 & $\begin{array}{c}\text { Writing Audio-Visual } \\
\text { scripts, Animations, } \\
\text { Studio production }\end{array}$ & Banani, Dhaka-1213 \\
\hline SW Multimedia Ltd & 2006 & $\begin{array}{c}\text { Web Site Design, 2D } \\
\text { Animation }\end{array}$ & $\begin{array}{c}\text { Banani, Dhaka-1213, Tel : } \\
+88029884434\end{array}$ \\
\hline Sketch Studio Limited & 2005 & $\begin{array}{c}\text { Animation, Motion } \\
\text { Graphics }\end{array}$ & Rampura, Dhaka-1217 \\
\hline $\begin{array}{l}\text { National Institute of Mass } \\
\text { Communication (NIMC) }\end{array}$ & 1980 & Training & $\begin{array}{l}\text { Darus Salam, Dhaka-1216 } \\
\text { Contact : +880-2-803-5958 }\end{array}$ \\
\hline Studio CLICK.HOUSE & 2007 & Animation & N/A \\
\hline RTC Hubs private Ltd. & 2010 & $\begin{array}{c}\text { Animation, Game } \\
\text { Developing }\end{array}$ & Uttara-7, Dhaka \\
\hline Toon Bangla & N/A & Animation & $\begin{array}{c}\text { Satmasjid Road, Dhanmondi, } \\
\text { Dhaka }\end{array}$ \\
\hline Roopokar Creative Studio & 2010 & $\begin{array}{c}\text { Animation, Graphic } \\
\text { design }\end{array}$ & N/A \\
\hline Kento Studios LTD & 2006 & Animation & Uttara,Dhaka \\
\hline
\end{tabular}


Table 2 summarizes information that we collected from different multimedia industries. There are some institutes in Bangladesh who offer different skill development programs including certificate course, diploma, advance diploma and degree programs. Only three private institutes are offering Bachelor degree programs on multimedia technology. There is no public university that offers any degree program on animation as well as multimedia design. Table 3 is shown the details program offering institutions on animation in Bangladesh.

Table 3 Skill development institutes that offer programs

\begin{tabular}{|l|l|}
\hline \multicolumn{1}{|c|}{ Name of the Institute } & \multicolumn{1}{c|}{ Type of Program } \\
\hline National Institute of Mass Communication & Diploma, Certificate \\
\hline Daffodil International University & BSC in Multimedia Technology and Creative Arts \\
\hline Daffodil International Professional Training Institute & Diploma, Certificate \\
\hline Santo-Maria University of Creative Technology & BA in GDM, ND \& HND \\
\hline American International University Bangladesh & BA in Multimedia and Mass Communication \\
\hline
\end{tabular}

\section{CONCLUSIONS}

There was not any animation institute in Bangladesh, recently a few institutes has started to provide animation courses for producing skilled professionals. They started through the help of other countries such as India, Malaysia, Philippine, Singapore etc. Now it is developing and getting accomplishment in this field. In this research the researchers found large possibilities on business sector. We surveyed the local animation industry and elicited information from the directors. According to their opinions, this sector needs skill hands in various part of animation through training and courses. Because this is the way we can improve and empower our population in this sector. Compared to other those countries, it is noted that Bangladesh can provide low-priced of any kind of animation product. The training has already started as diploma course, certificate course, bachelor course also in a few institutes of government and private. All these courses are related to multimedia but not fully animation course. If any meaningful progress in this sector locally, Bangladesh should take the initiatives to enhance on all kind of animation oriented programs at both academic and private sector levels.

\section{ACKOWLEDGEMENT}

We are very much thanks to all animation industries who served as responses to this research specially Dreamer Donkey, Ogniroth, Dot 3 Production (Pvt) Ltd, AAVA 3D and Daffodil International Professional Training Institute, RTC Hubs Private Ltd, for giving their valuable time to provide information. We also are thanking to all other animation studios that is assisted us in different ways.

\section{REFERENCES}

[1] Islam, M Baharul (2013), "Motion analysis using distance and velocity-time function", International Journal on Scientific Knowledge (Computing and Information technology), Vol. 2, No. 2, pp 1-6. 
International Journal of Computer Graphics \& Animation (IJCGA) Vol.3, No.3, July 2013

[2] Edwin Michael, Afi Roshezry Abu Bakar, Ira Meilita Ibrahim, Geetha Veerappan, Norazleen Mohamad Noor, Lim Ean Heng, Taufik A. Latif, Ng Kar Yann, (2012) "A Comparative Study of Gender Roles in Animated Films”, Global Journal of Human Social Science, Vol. 12, No. 5, Version 1.0.

[3] Hye-Kyung LEE (2010), “Animation industry at a crossroads”, Creative Industries Journal, Vol. 3, No. 3 , pp 183-187.

[4] Steve Roberts (2007), “Character Animation: 2D skills for better 3D”, second edition, Focal press (is an imprint of Elsevier), Jordan Hill, Oxford, UK.

[5] Shegufta Yasmin (2011), "Contemporary Bangladeshi Commercial Cinema: A Perspective from Young Generation of Bangladesh”, ASA University Review, Vol. 5 No. 1, pp. 175-194.

[6] National budget (2012), Ministry of Finance, Bangladesh.

www.mof.gov.bd/en/budget/ 12_13/budget_speech/speech_en.pdf

[7] Zheng Liu, Yongjiang Shi (2010), "A study on current business performance of Chinese animation industry”, Conference Papers for Chinese Economic Association (UK/Europe) Conference, Oxford, UK.

[8] Market Study on Animation and Gaming Industry in India for Italian Trade Commission, TATA Strategic management group (A division of TATA Industries Ltd), February 2010, Mumbai 400021, India,

www.tsmg.com

[9] Harold Whitaker and John Halas (1981), “Timing for Animation”, Focal press (is an imprint of Elsevier), Jordan Hill, Oxford, UK.

[10]Doing Business In Bangladesh: A Country Commercial Guide for U.S. Companies, Guide from Department of State, 2006, USA.

[11]Report on Copyright Protection and Enforcement, International Intellectual property Alliance (IIPA) 2009 Special 301, Bangladesh, pp. 369-373, Issued February 17, 2009.

www.iipa.com/rbc/2009/2009SPEC301INDIA.pdf

[12] Jehoshua Eliashberg, Anita Elberse, Mark A.A.M. Leenders (2006), "The motion Picture Industry: Critical Issues in Practice, Current Research and New Research Directories", Journal of Marketing Science, vol. 25, no. 6, pp. 638-661.

[13] Herwina Rosnan, Zarith Delaila, Abdul Aziz (2012) "Film Business in Malaysia: Challenges and Opportunities”, International Journal of Humanities and Social Science, Vol. 2 No. 12, pp. 198-202.

[14]Ran Li, Kiyoshi Tomimatsu, Toru Kodama (2010) “Analysis of Major Problems Existing in Chinese Animation Industry"

www.design.kyushu-u.ac.jp

[15] Ted Tschang, Andrea Goldstein (2004), "Production and Political Economy in the Animation Industry: Why In-sourcing and Out-sourcing Occur", Industrial Dynamics Innovation and Development (DRUID Summer Conference), Elsinore, Denmark, June 14-16.

[16] Yamada Ken-ichi (2013) "Market competition in Animation industries between Japan and China: How to face China's raising interest in promoting Domestically-Produced Animation" NHK Broadcasting Culture Research Institute (Media Research and Studies).

[17] Michael D. Mattesi (2008) "Force Character Design from Life Drawing”, Focal press (is an imprint of Elsevier), Jordan Hill, Oxford, UK.

[18]Richard Taylor (2013) "The Encyclopaedia of Animation Techniques", Page One Publishing Private Limited, pp. 7. 
International Journal of Computer Graphics \& Animation (IJCGA) Vol.3, No.3, July 2013

[19] Frank Thomas and Ollie Johnston (1981) "The Illusion of Life Disney Animation”, Walt Disney Production.

[20]Economic Contribution of the Film and Television Industry (2011) Report by Access Economics Pty Limited for AFACT.

\section{Authors Biography:}

Md. Baharul Islam is a Senior Lecturer of Multimedia Technology and Creative Arts at Daffodil International University, Bangladesh. His research interests include: image processing, modeling and reconstructions, medical imaging, computer animation. $\mathrm{He}$ received best paper award from Global Engineering, Science and Technology Conference 2012, Dhaka, Bangladesh. He has published many international journals and presented in several conferences. He also received fellowship from Global Institute of science and Technology, Victoria, Australia in 2013. He is a member of the Institute of Engineers, Bangladesh. Author worked in some international institutions like: University, College and reputed IT firms in different countries e.g. Bangladesh, Singapore, and Malaysia.

Abu Kalam Shamsuddin is a Lecturer of Multimedia and Creative Arts at Daffodil International University,Dhaka, Bangladesh. He received M.F.A from Rajshahi University, Bangladesh in 2008. His research interests are in computer animation, Concept art, Typography. He has work experience in teaching field for three years in Santo-Mariam University of Creative Technology, Dhaka, Bangladesh.

Golam Moshiur Rahman Choudhury is CEO and Managing Director of Dreamer Donkey Limited, Bangladesh. He received M.A. in Animation from University Technology Mara Malaysia in 2011 and Diploma in animation and multimedia from Limkokwing University of Creative Technology Malaysia, in 2006. He also received BFA honors in Fine Arts (drawing and painting) in 1999 from Dhaka University. His research interests include visual identification, and 3D animation. He received many awards for creative and academic excellence. He is a member of the Society of Animation Studies (SAS), and worked as faculty member in some international well-reputed academic
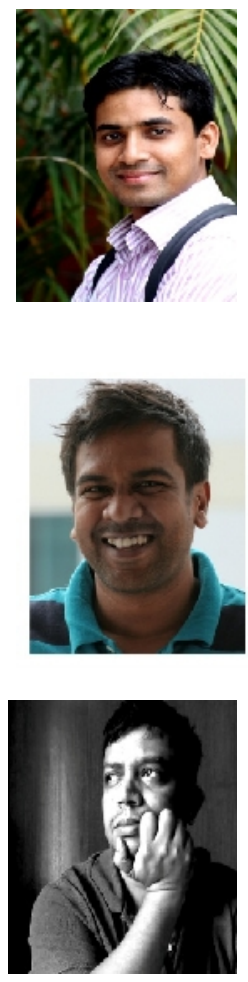
institutions such as Limkokwing University of Creative Technology Malaysia, Linton University collage, East London University (Malaysia). He also works as a consultant with several animation studios both with Bangladesh and outside. 